\title{
Reclassification of Paralactobacillus selangorensis Leisner et al. 2000 as Lactobacillus selangorensis comb. nov.
}

\author{
Monique Haakensen, Vanessa Pittet and Barry Ziola \\ Department of Pathology and Laboratory Medicine, University of Saskatchewan, \\ 2841 Royal University Hospital, 103 Hospital Drive, Saskatoon, SK S7N OW8, Canada
}

Correspondence

Barry Ziola

b.ziola@usask.ca

\begin{abstract}
The taxonomic status of Paralactobacillus selangorensis is described and, based on evidence presented, transfer of the species to the genus Lactobacillus with the name Lactobacillus selangorensis comb. nov. is proposed. This reclassification is supported by multilocus sequence analysis of the 16S rRNA gene and portions of the cpn60, pheS and rpoA genes. Mode of cell division and existing phenotypic information also show that $P$. selangorensis cannot be differentiated from the genus Lactobacillus. The type strain of Lactobacillus selangorensis comb. nov. is ATCC BAA-66 ${ }^{\top}$ (=LMG $17710^{\top}=$ CIP $\left.106482^{\top}\right)$.
\end{abstract}

\section{INTRODUCTION}

Consisting of a single species, the genus Paralactobacillus was first mentioned in 1997 (Leisner et al., 1997) and the genus name was validly published in 2000 (Leisner et al., 2000). At the time of description, Paralactobacillus selangorensis was only compared to select subsets of species of the genus Lactobacillus, thereby giving the appearance that it was a separate genus (Leisner et al., 1997, 1999, 2000). Specifically, phenotypic comparison was done with only seven and fifteen species from the Lactobacillus casei/ Pediococcus and Lactobacillus delbrueckii groups, respectively, thus ignoring more than one hundred other species of the genus Lactobacillus described at that time (Leisner et al., 2000). Moreover, in the same study, the 16S rRNA gene phylogeny that was done included only three species for each of the same two comparative Lactobacillus groups. Other authors have since shown by $16 \mathrm{~S}$ rRNA gene phylogeny that $P$. selangorensis, in fact, resides in the midst of the genus Lactobacillus (Ennahar et al., 2003; Hammes \& Hertel, 2006; Ljungh \& Wadstrom, 2009), but no formal request for reclassification has been made. Here we show that by conducting phylogenetic analysis based on four conserved genetic loci, and by including species of the genus Lactobacillus representative of all major Lactobacillus groups (as defined by Hammes \& Hertel, 2006), the genus Paralactobacillus does not warrant separate genus status, but rather the single species of the genus belongs in the genus Lactobacillus.

\footnotetext{
Abbreviation: MLSA, Multilocus sequence analysis.

The GenBank/EMBL/DDBJ accession numbers for the cpn60, rpoA and pheS gene sequences of strain ATCC BAA- $66^{\top}$ are HM214469, HM214470 and HM214471, respectively.

A supplementary figure is available with the online version of this paper.
}

\section{METHODS}

Multilocus sequence analysis (MLSA). Although 16S rRNA gene sequences are commonly used to elucidate phylogenetic relationships, using only a single gene to infer phylogeny has been criticized as it assumes that one molecule can reflect organismal evolutionary history (Fox et al., 1992). In the same manner as that applied to clarify the taxonomic position of Pediococcus dextrinicus within the genus Lactobacillus (Haakensen et al., 2009), we used a MLSA to assess the relationship of $P$. selangorensis to species of the genus Lactobacillus and species of related genera. In addition to the full-length $16 \mathrm{~S}$ rRNA gene, we analysed portions of the conserved genes cpn60 (552 bp), pheS (455 bp) and rpoA (533 bp).

Phylogenetic trees were reconstructed using GenBank accessible sequences for type strains of the genus Lactobacillus. cpn60, pheS and rpoA gene sequences were aligned by using CLUSTAL x (Thompson et al., 1997) and 16S rRNA gene sequences were aligned using the tools available in the myRDP section of the Ribosomal Database Project (RDP) website (Cole et al., 2007, 2009). DNA extracted from $P$. selangorensis ATCC BAA- $66^{\mathrm{T}}$ was used for amplification and sequencing of cpn60, pheS and rpoA gene sequences as previously described (Haakensen et al., 2009). Tree topology was evaluated using minimum-evolution, maximum-parsimony, neighbour-joining and unweighted pair group method of arithmetic means algorithms, with all methods producing similar overall topologies (data not shown). Trees shown in Fig. $1(\mathrm{a}-\mathrm{d})$ were inferred by using the neighbourjoining maximum composite likelihood method (Saitou \& Nei, 1987) for the 16S rRNA, cpn60, pheS and rpoA genes and are representative of the topology reconstructed by all four algorithms. Due to space constraints, the $16 \mathrm{~S}$ rRNA gene tree (Fig. 1a) was reconstructed using only sequences from two representatives from each of the seven groups of the genus Lactobacillus as described in The Prokaryotes (Hammes \& Hertel, 2006). By using two representatives from each of these seven groups, the overall structure of the 16S rRNA gene tree remains the same as that shown in more extensive investigations regarding taxonomy of the genus Lactobacillus (Collins et al., 1991; Stiles \& Holzapfel, 1997; Klein et al., 1998; Holzapfel et al., 2001; Hammes \& Hertel, 2006; Felis \& Dellaglio, 2007; Naser et al., 2007; Supplementary Fig. S1, available in IJSEM Online, which contains the 16S rRNA gene phylogenetic tree reconstructed using RDP data 


\section{(a)}
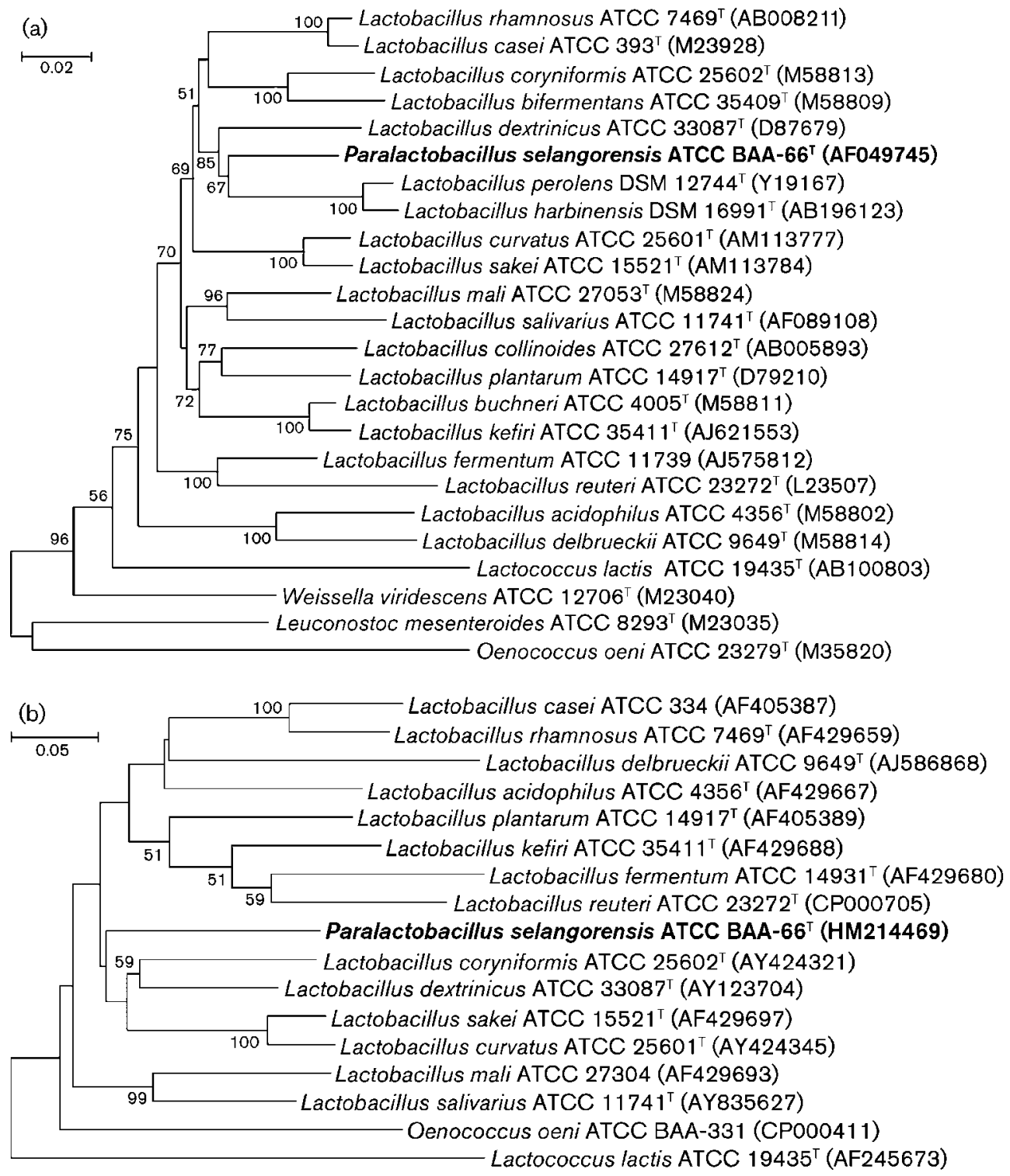

(c)

- Lactobacillus coryniformis ATCC $25602^{\top}$ (AM087684)

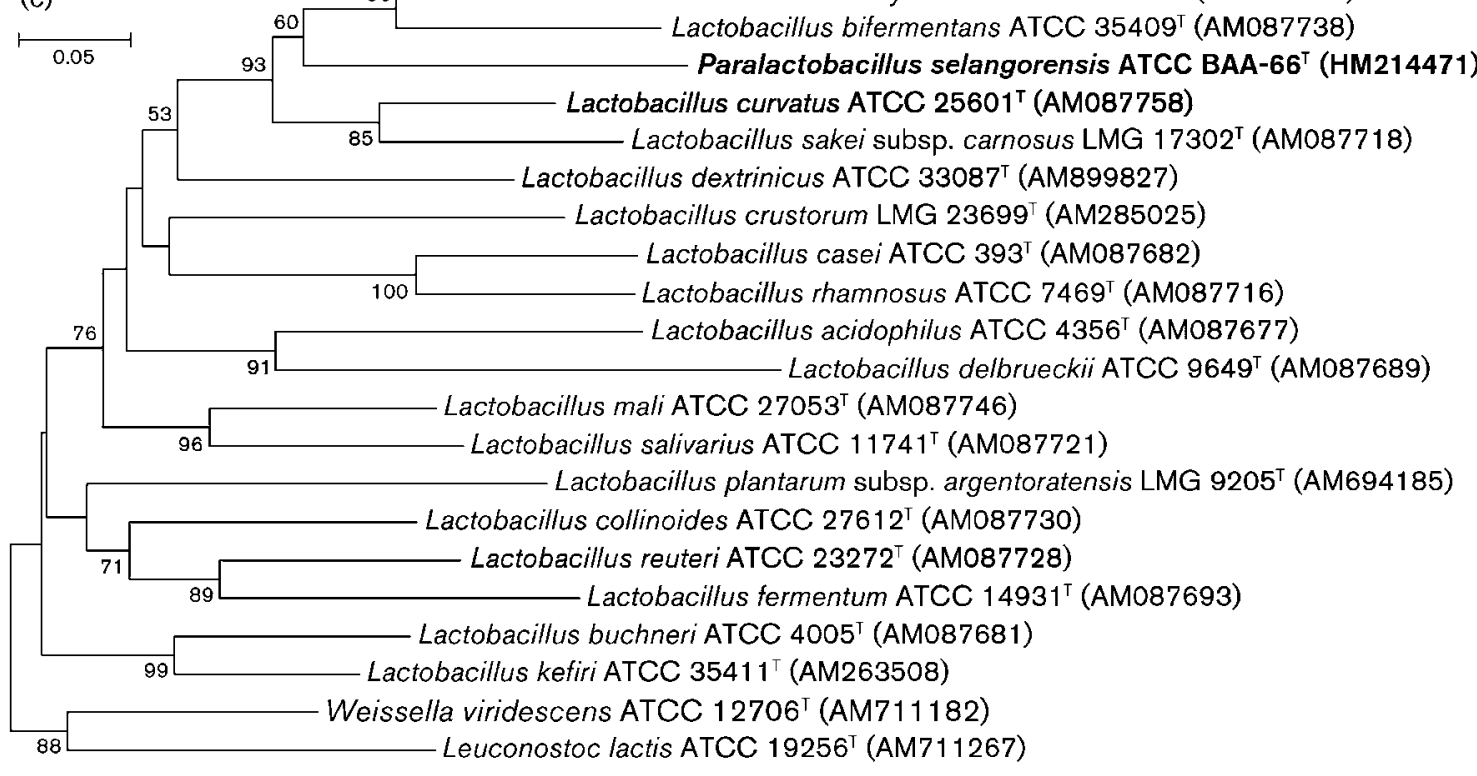




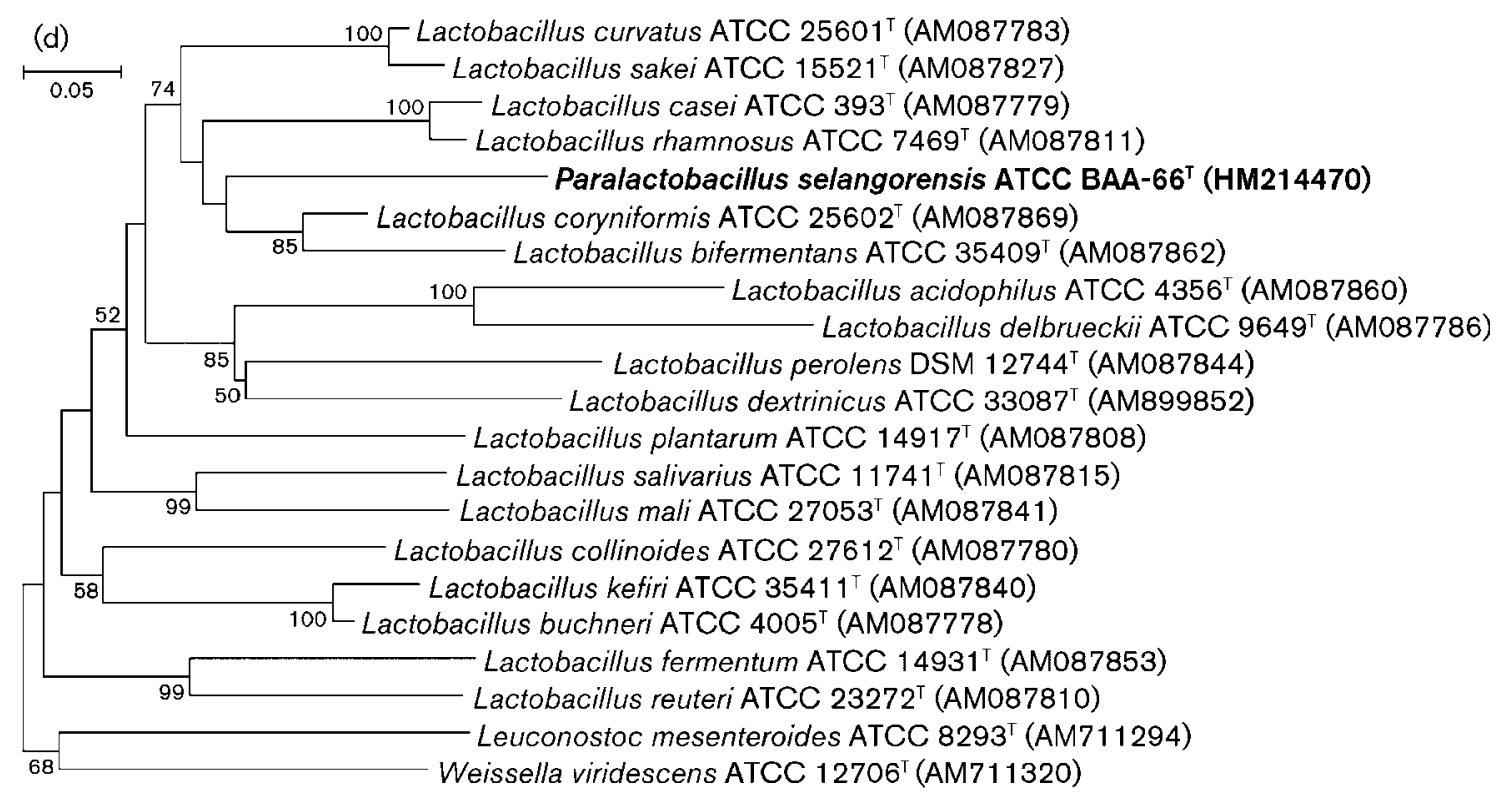

Fig. 1. Phylogenetic trees illustrating the evolutionary relationship of Paralactobacillus selangorensis to species representative of the major clades of the genus Lactobacillus. Where sequences were available, Lactococcus lactis, Leuconostoc lactis, Leuconostoc mesenteroides, Oenococcus oeni and Weissella viridescens have been included as outliers. GenBank accession numbers are given in parentheses. Bootstrap values $>50 \%$ are given at nodes as a percentage of 1000 replicates. (a) $16 \mathrm{~S}$ rRNA gene; bar, $2 \%$ divergence; (b) cpn60; bar, $5 \%$ divergence; (c) pheS; bar, $5 \%$ divergence; (d) rpoA; bar, $5 \%$ divergence.

accessed 1 December 2010 for the type strains of all species of the genera Lactobacillus and Pediococcus, as well as for the type strain of Paralactobacillus selangorensis and one other isolate). The cpn60, pheS and $r p o A$ trees (Fig. $1 \mathrm{~b}-\mathrm{d}$ ) were reconstructed using available sequences for the isolates of the species of the genus Lactobacillus used to create the $16 \mathrm{~S}$ rRNA gene tree. Also, when available, sequences of isolates from the closely related genera Lactococcus, Leuconostoc, Oenococcus and Weissella were included as outliers for each tree. All phylogenetic trees were produced and visualized using MEGA version 4.0 (Tamura et al., 2007). The percentage of replicate trees in which the associated taxa clustered together $(>50 \%)$ in the bootstrap test (1000 replicates) are shown next to the branches (Felsenstein, 1985).

Comparison of phenotypic properties. Multiple and diverse phenotypic properties have been published for species of the genus Lactobacillus. Excellent summaries of these phenotypes can be found in books and book chapters by Dellaglio \& Torriani (1986), Hammes \& Hertel (2006) and Ljungh \& Wadstrom (2009). For purposes of comparison in this paper, phenotypic traits previously published for P. selangorensis (Leisner et al., 1997, 1999, 2000) were compared to known phenotypes of the genus Lactobacillus (Table 1).

\section{RESULTS AND DISCUSSION}

The description of Paralactobacillus selangorensis was based on phenotypic comparisons and $16 \mathrm{~S}$ rRNA gene phylogeny involving only a restricted number of species of the genera Lactobacillus and Pediococcus (Leisner et al., 2000). In addition, the species chosen for the comparative analyses represented only two of the major Lactobacillus groups currently defined (Hammes \& Hertel, 2006). Given how the genus Paralactobacillus was established, our goal was to determine whether this genus truly is a separate genus, or whether it should be renamed to reflect classification within an existing genus.

Phylogeny of the 16S rRNA gene has previously shown that $P$. selangorensis resides taxonomically within the genus Lactobacillus (Ennahar et al., 2003; Hammes \& Hertel, 2006; Ljungh \& Wadstrom, 2009). To confirm and extend these findings, we applied a MLSA approach to further assess the taxonomic relationship of the genus Paralactobacillus with the genus Lactobacillus. Phylogenetic trees were reconstructed by using sequences of the 16S rRNA gene and portions of the cpn60, pheS and rpoA genes (Fig. 1a-d, respectively). As shown in both Fig. 1(a) and in the comprehensive 16S rRNA gene phyologenetic tree found in Supplementary Fig. S1, $P$. selangorensis is located within the genus Lactobacillus. The phylogenetic trees reconstructed with portions of the $c p n 60$, pheS and $r p o A$ genes also place $P$. selangorensis firmly within the genus Lactobacillus (Fig. 1b-d). This taxonomic placement for $P$. selangorensis is congruent with the previously published 16S rRNA gene sequence analyses of the genus Lactobacillus which have included P. selangorensis (Ennahar et al., 2003; Hammes \& Hertel, 2006; Ljungh \& Wadstrom, 2009). As well, when phenotypic data are assessed, $P$. selangorensis cannot be differentiated from accepted phenotypic variances already recognized in species of the genus Lactobacillus (Table 1). 
Table 1. Phenotypic characteristics of $P$. selangorensis and the genus Lactobacillus

+ , Positive; - , negative; $+/-$, genus includes species that are both positive and negative for that phenotype. Data adapted from Dellaglio \& Torriani (1986), Hammes \& Hertel (2006) and Leisner et al. (1997, 1999, 2000).

\begin{tabular}{|lcc|}
\hline Characteristic & Paralactobacillus & Lactobacillus \\
\hline Production of acid from: & - & $+/-$ \\
Starch & - & $+/-$ \\
Mannitol & - & $+/-$ \\
Raffinose & DL & D, L $(+)$, DL \\
Configuration of lactate & & \\
Growth with/at: & - & $+/-$ \\
$6.5 \% \mathrm{NaCl}$ & + & $+/-$ \\
$\mathrm{pH} 4.5$ & - & $+/-$ \\
$45{ }^{\circ} \mathrm{C}$ & - & $+/-$ \\
Strictly anaerobic & & \\
\hline
\end{tabular}

Our MLSA findings (Fig. 1a-d) and available phenotypic information (Table 1) show that the genus Paralactobacillus does not warrant status as an independent genus. Rather, the data presented support the proposal that the sole species of this genus, $P$. selangorensis, represents a novel species of the genus Lactobacillus. Through reclassification of this organism, a better understanding of the characteristics and relationships of members of the genus Lactobacillus should be facilitated.

\section{Description of Lactobacillus selangorensis comb. nov.}

Lactobacillus selangorensis (sel.an.gor'en.sis. M.L. adj. selangorensis belonging to the province of Selangor, Malaysia).

Basonym: Paralactobacillus selangorensis Leisner et al. 2000.

The description for the species remains as described by Leisner et al. (2000), with the description of the genus Paralactobacillus (Leisner et al., 2000) being the description of Lactobacillus selangorensis.

The type strain is ATCC BAA $-66^{\mathrm{T}}\left(=\mathrm{LMG} 17710^{\mathrm{T}}=\mathrm{CIP}\right.$ $\left.106482^{\mathrm{T}}\right)$.

\section{ACKNOWLEDGEMENTS}

M.H. was awarded the Coors Brewing Company, Cargill Malt, and Miller Brewing Company Graduate Scholarships from the American Society of Brewing Chemists Foundation, and was the recipient of a Graduate Scholarship from the College of Medicine, University of Saskatchewan. V. P. was the recipient of the Anheuser-Busch InBev Graduate Scholarship from the American Society of Brewing Chemists Foundation and was the holder of a Canada Graduate Scholarship from the Natural Sciences and Engineering Research Council of Canada (NSERC). This research was supported by NSERC Discovery Grant 24067-05.

\section{REFERENCES}

Cole, J. R., Chai, B., Farris, R. J., Wang, Q., Kulam-Syed-Mohideen, A. S., McGarrell, D. M., Bandela, A. M., Cardenas, E., Garrity, G. M. \& Tiedje, J. M. (2007). The ribosomal database project (RDP-II): introducing myRDP space and quality controlled public data. Nucleic Acids Res 35 (Database issue), D169-D172.

Cole, J. R., Wang, Q., Cardenas, E., Fish, J., Chai, B., Farris, R. J., Kulam-Syed-Mohideen, A. S., McGarrell, D. M., Marsh, T. \& other authors (2009). The Ribosomal Database Project: improved alignments and new tools for rRNA analysis. Nucleic Acids Res 37 (Database issue), D141-D145.

Collins, M. D., Rodrigues, U., Ash, C., Aguirre, M., Farrow, J. A. E., Martinez-Murcia, A., Phillips, B. A., Williams, A. M. \& Wallbanks, S. (1991). Phylogenetic analysis of the genus Lactobacillus and related lactic acid bacteria as determined by reverse transcriptase sequencing of 16S rRNA. FEMS Microbiol Lett 77, 5-12.

Dellaglio, F. \& Torriani, S. (1986). DNA-DNA homology, physiological characteristics and distribution of lactic-acid bacteria isolated from maize silage. J Appl Bacteriol 60, 83-92.

Ennahar, S., Cai, Y. \& Fujita, Y. (2003). Phylogenetic diversity of lactic acid bacteria associated with paddy rice silage as determined by $16 \mathrm{~S}$ ribosomal DNA analysis. Appl Environ Microbiol 69, 444-451.

Felis, G. E. \& Dellaglio, F. (2007). Taxonomy of Lactobacilli and Bifidobacteria. Curr Issues Intest Microbiol 8, 44-61.

Felsenstein, J. (1985). Confidence limits on phylogenies: an approach using the bootstrap. Evolution 39, 783-791.

Fox, G. E., Wisotzkey, J. D. \& Jurtshuk, P., Jr (1992). How close is close: $16 \mathrm{~S}$ rRNA sequence identity may not be sufficient to guarantee species identity. Int J Syst Bacteriol 42, 166-170.

Haakensen, M., Dobson, C. M., Hill, J. E. \& Ziola, B. (2009). Reclassification of Pediococcus dextrinicus (Coster and White 1964) Back 1978 (Approved Lists 1980) as Lactobacillus dextrinicus comb. nov., and emended description of the genus Lactobacillus. Int J Syst Evol Microbiol 59, 615-621.

Hammes, W. P. \& Hertel, C. (2006). The genera Lactobacillus and Carnobacterium. In The Prokaryotes, 3rd edn, vol. 4, pp. 320-403. Edited by M. Dworkin, S. Falkow, E. Rosenberg, K.-H. Schleifer \& E. Stackebrandt. New York, NY: Springer.

Holzapfel, W. H., Haberer, P., Geisen, R., Björkroth, J. \& Schillinger, U. (2001). Taxonomy and important features of probiotic microorganisms in food and nutrition. Am J Clin Nutr 73 (Suppl.), 365S373 S.

Klein, G., Pack, A., Bonaparte, C. \& Reuter, G. (1998). Taxonomy and physiology of probiotic lactic acid bacteria. Int J Food Microbiol 41, 103-125.

Leisner, J. J., Rusul, G., Wee, B. W., Boo, H. C. \& Muhamad, K. (1997). Microbiology of chili bo, a popular Malaysian food ingredient. J Food Prot 60, 1235-1240.

Leisner, J. J., Pot, B., Christensen, H., Rusul, G., Olsen, J. E., Wee, B. W., Muhamad, K. \& Ghazali, H. M. (1999). Identification of lactic acid bacteria from chili bo, a Malaysian food ingredient. Appl Environ Microbiol 65, 599-605.

Leisner, J. J., Vancanneyt, M., Goris, J., Christensen, H. \& Rusul, G. (2000). Description of Paralactobacillus selangorensis gen. nov., sp. nov., a new lactic acid bacterium isolated from chili bo, a Malaysian food ingredient. Int J Syst Evol Microbiol 50, 19-24.

Ljungh, A. \& Wadstrom, T. (2009). Lactobacillus Molecular Biology: From Genomics to Probiotics. Norfolk, UK: Caister Academic Press.

Naser, S. M., Dawyndt, P., Hoste, B., Gevers, D., Vandemeulebroecke, K., Cleenwerck, I., Vancanneyt, M. \& Swings, J. (2007). 
Identification of lactobacilli by pheS and rpoA gene sequence analyses. Int J Syst Evol Microbiol 57, 2777-2789.

Saitou, N. \& Nei, M. (1987). The neighbor-joining method: a new method for reconstructing phylogenetic trees. Mol Biol Evol 4, 406425.

Stiles, M. E. \& Holzapfel, W. H. (1997). Lactic acid bacteria of foods and their current taxonomy. Int J Food Microbiol 36, 1-29.
Tamura, K., Dudley, J., Nei, M. \& Kumar, S. (2007). MEGA4: molecular evolutionary genetics analysis (MEGA) software version 4.0. Mol Biol Evol 24, 1596-1599.

Thompson, J. D., Gibson, T. J., Plewniak, F., Jeanmougin, F. \& Higgins, D. G. (1997). The CLUSTAL_X windows interface: flexible strategies for multiple sequence alignment aided by quality analysis tools. Nucleic Acids Res 25, 4876-4882. 